\title{
The influence of weapons of mass destruction on international security in the second decade of the 21st century
}

\author{
Wpływ broni masowego rażenia \\ na bezpieczeństwo międzynarodowe \\ w II dekadzie XXI wieku
}

\author{
Włodzimierz Wątor*
}

\begin{abstract}
The article outlines reasons for the significant increase of the hazard posed by weapons of mass destruction in the current decade. Despite the international community's efforts made throughout the years, it has not been possible to eliminate them, significantly lower their arsenal or prevent their building or transfer. What has increased is the importance of weapons of mass destruction, especially nuclear ones, as a force factor in international relations. This tendency will probably continue in the foreseeable future. Therefore, the article focuses on explaining the mechanisms of this process and its connections with numerous events and facts influencing international security. Special significance
\end{abstract}

\begin{abstract}
Abstrakt
W artykule przedstawiono przyczyny, dla których w ciągu obecnej dekady nastąpił znaczący wzrost zagrożenia bronią masowego rażenia. Pomimo wieloletnich wysiłków społeczności międzynarodowej broni tej nie udało się wyeliminować ani znacząco ograniczyć jej arsenałów czy też wykluczyć możliwość jej budowy lub transferu. Wzrosło natomiast znaczenie broni masowego rażenia, zwłaszcza jądrowej, jako czynnika siły w stosunkach międzynarodowych. Tendencja ta prawdopodobnie utrzyma się $\mathrm{w}$ dającej się przewidzieć przyszłości. Dlatego też podczas opracowywania artykułu skoncentrowano się na wyjaśnieniu mechanizmów tego procesu i jego powiązań z wieloma innymi wyda-
\end{abstract}

* Akademia Sztuki Wojennej (Centrum Szkolenia Obrony Przed Bronia Masowego Rażenia w SZ RP); (e-mail: wwm_wator@wp.pl);

iD https://orcid.org/0000-0002-9402-5350. 
is ascribed to a precise estimation of the risk posed by weapons of mass destruction and determination of its hierarchy. Moreover, the article presents the forms and methods of the activities undertaken by countries and international organisations regarding the prevention of proliferation (via disarmament treaties and informal forums) and assesses their effectiveness.

Key words: weapon of mass destruction, proliferation, nuclear deterrence, disarmament rzeniami i faktami mającymi wpływ na bezpieczeństwo międzynarodowe. Należy tu podkreślić szczególne znaczenie, jakie przypisano roli precyzyjnego szacowania ryzyka stwarzanego przez broń masowego rażenia i określeniu jego hierarchii. Ponadto przedstawiono formy $\mathrm{i}$ metody działania państw i organizacji międzynarodowych w zakresie zapobiegania proliferacji (w ramach traktatów rozbrojeniowych i forów nieformalnych) oraz dokonano oceny ich efektywności.

Słowa kluczowe: broń masowego rażenia, proliferacja, odstraszanie nuklearne, rozbrojenie

\section{Introduction}

Weapons of mass destruction (WMD) is a conventional name of a set comprising different categories and subcategories of so-called unconventional weapons. ${ }^{1}$ Due to the highly destructive impact on people, infrastructure and the environment, it constitutes a significant hazard to regional and global security. This is confirmed by various examples of using the individual WMD types in international and internal armed conflicts as well as terrorist attacks.

When one limits the article scope to the present decade of the 21st century, about a dozen of such incidents have been recorded in the world. The most spectacular of them were reported on by mass media. However, little is known about the remaining ones as they caused smaller losses or took place in inaccessible zones, e.g. due to ongoing fights.

The chemical attacks of 2013-2018 in Syria prove that reconnaissance ${ }^{2}$ and identification $^{3}$ of the used toxic substances is insufficient for the purposes of

${ }^{1}$ One of the first definitions of weapons of mass destruction was published in 1948 in a resolution by the United Nations Commission on Conventional Armaments. It states that WMD includes "atomic explosive weapons, radioactive material weapons [and] certain 'lethal' chemical and biological weapons".

${ }^{2}$ Contamination reconnaissance - an action aimed at determining the presence of radioactive substances or biological or chemical agents as well as supplementing and conforming the preliminary dispatches. See Regulation of the Council of Ministers of 7 January 2013 on contamination detection and announcement as well as competence of authorities in these matters (\$2, par. 10), Dz.U. of 2013, item 96.

${ }^{3}$ Contamination identification - actions aimed at determining the asset type used during an attack (incident). It includes sampling of contaminated materials as well as transport and a laboratory analysis of the samples. The evidence analysis mentioned in the text 
evidence proceedings, which hinders unambiguous identification of perpetrators. This is caused first and foremost by the fact that every stage of the WMD acquisition and development programmes as well as the planning and preparation of attacks is a strictly guarded secret.

The wide series of the assets enabling operational use of weapons of mass destruction (rocket missiles and artillery, aircraft, submarines) is continuously modernised, i.a. concerning their range, throw-weight and CEP. ${ }^{4}$

The indispensable high level of technological advancement makes the WMD development and modernisation programmes very costly. Nevertheless, according to Kenneth Waltz's theory, selected countries attempt to acquire WMD, especially nuclear weapons, in order to counterbalance their position in relation to a potential enemy which already owns such weapons. Another significant fact is participation in the international deterrence mechanisms and building a much more effective military potential as an alternative to long-long-lasting and increasingly expensive conventional armament.

In such situation, the diversified forms of combating the proliferation ${ }^{5}$ of weapons of mass destruction, especially those concerning armament control and so-called non-proliferation initiatives, constitute one of the priority tasks for individual countries, groups of countries and international organisations. Due to the heterogeneous nature of WMD programmes as well as the dynamism of the hard-to-predict phenomena and processes which accompany them, those actions are largely uncertain. ${ }^{6}$ This makes one ask a number of ontological questions concerning the risk posed by WMD and its proliferation, which is expressed as a product of the probability of an attack (incident) and its health-related, political, sociological, economic and environmental effects. ${ }^{7}$ Consequently, it is

is conducted by certified laboratories using scientifically validated analytical methods. See more in: Obrona przed bronia masowego rażenia w operacjach połaczonych DD/3.8(A), Bydgoszcz 2013, p. 34-35.

4 Throw-weight - a concept introduced by the Strategic Arms Limitation Treaty (SALT I) of 26 May 1972. It enables the classification of ballistic missiles. It denotes the maximum weight a missile can carry including the weight of all of its elements, e.g. the navigation and guidance systems, excluding the weight of engines and fuel. CEP (circular error probable) a coefficient enabling one to calculate the probability of target destruction. It is defined as the radius of the circle within which $50 \%$ of launched rocket missiles will end their flight.

${ }^{5}$ Proliferation (Latin: proles — progeny, fero - I carry) — a term taken from biological sciences which means growth and multiplication. Its Polish equivalents are "spreading" and "dissemination".

${ }^{6}$ Uncertainty in decision theory - a situation where specific decisions may cause various effects depending on which possible state of affairs actually takes place, but no occurrence probability is known. Source: Encyklopedia Zarzadzania (an online management encyclopaedia). Cf. Z. Redziak: Niepewność w podejmowaniu decyzji. "Zeszyty Naukowe AON" 2013, nr 2(91), p. 102.

7 J. Wolanin: Zarys teorii bezpieczeństwa obywateli. Ochrona ludności na czas pokoju. Warsaw 2005, p. 26. 
natural to search for effective methods of risk analysis ${ }^{8}$ and assessment which translate into projects aiming at its reduction. Those are usually actions in the political, economic, legal or military domain.

The inspiration to write this article is the noticeable need for the information which enables one to assess the risk posed by WMD as well as for the knowledge which facilitates the forecasting of its changes in the future, with particular reference to the hazard-reducing actions undertaken by countries and specialised departments of international organisations. An additional aim of the article is to present WMD implications for international security and the contemporary political relations. The aim defined this way has resulted in the formulation of research problems as the following questions:

- What is the hierarchy of the risk posed by WMD types and can its acceptability level be defined?

- What is the actual influence of WMD and its delivery programmes on international security and political relations ${ }^{9}$ in the second decade of the 21 st century?

- What actions do countries and international organisations take to limit WMD proliferation and what is the effectiveness of those actions?

Due to the limited number of publicly available sources (WMD data are usually classified as top secret), the adopted research methodology assumes an analysis and interpretation of all the available information sources, which are often fragmentary. A helpful factor in this situation is the author's long-term experience in analytical work aimed at the preparation of assessments and forecasts concerning WMD hazard (for Poland and various regions of the world) as well as practical solutions related to protection against the destructive impact of WMD. A significant research mechanism referred to in this article is the analysis of selected cases of WMD use and modelling the effects of hypothetical incidents with decision-support software.

${ }^{8}$ Risk analysis - determination of a scenario according to which the risk may come true, i.e. a hazard will turn into a disruption, an incident or a disaster. This is influenced by the emergence mechanism of a given hazard, the susceptibility to that hazard in local conditions and the ability to react to the effects. A. KosieradzKa, J. ZaWILA-Niedźwiecki: Zaawansowana metodyka oceny ryzyka w publicznym zarządzaniu kryzysowym. KrakówLegionowo 2016, p. 42.

9 "International political relations are interactions between entities the actions of which go beyond their own boundaries and take place in a polyarchic, polycentric and decentralised environment... International political relations are relationships between independent and non-independent entities in which politics plays the superior role". See more in: P. OstaszewSKI: Międzynarodowe stosunki polityczne. Zarys wykładów. Warszawa 2008, p. 12. 


\section{WMD risk assessment}

Weapons of mass destruction include separate categories of combat assets; the differences between them concern the technical issues regarding their manufacturing and possible use as well as the methods of preventing their use and mitigating the effects.

One of the important threads discussed in this article is consideration for the stances of the countries which already possess or strive to acquire WMD arsenals. These are expressed in their military doctrines. Therefore, it is necessary to divide WMD risk into separate categories (risk segmentation) corresponding to the adopted division into types within that set (chemical, biological, radiological and nuclear weapon). This assumption defines the pivot of the research deliberations and influences the article structure.

The risk analysis and hierarchisation model chosen as optimal for the purposes of this section is the model by FEMA (US Federal Emergency Management Agency). It utilises four partial meters: incident frequency in the past, susceptibility defining the population number and property value exposed to the hazard, the maximum hazard together with the surface area influenced by the effects (including the scenario of the most unfavourable incident) and incident probability in the whole year. Each of those meters receives a weight and is assessed using points from 0 to 10 . The hazard degree is a product of the weight and the points. The calculation results obtained using this method reflect the degree of the current hazard caused by various WMD types. They are presented in the diagram below.

Hazard degree

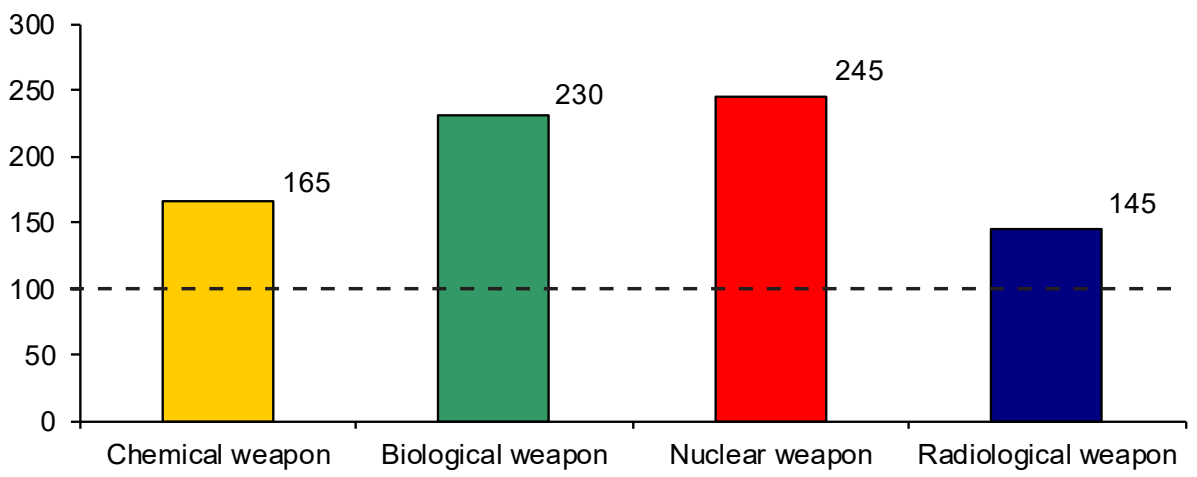

Fig. 1. The WMD hazard degree in the second decade of the 21st century according to the FEMA model. Developed by the author. 
First, the presented distribution of the aggregated hazard value confirms the necessity of analysing each WMD type separately; second, it inspires one to search for detailed justifications for the determined risk hierarchy. This simultaneously constitutes the starting point for subsequent deliberations. The data used for the calculations are relative, ${ }^{10}$ so the results are approximate and are used first and foremost to define the structure and intensity of the individual hazards in the analysed set. Still, even these approximate results show that all WMD types are sources of risk which exceeds so-called acceptable (tolerable) ${ }^{11}$ level (100 in the FEMA model) by 0.5 times for radiological weapon and up to 1.5 times for nuclear weapon.

The risk acceptability concept is related to the ALARP (as low as reasonably possible) principle, according to which the risk level should be kept as low as possible and if the acceptability limit is exceeded, it becomes necessary to undertake all the risk-reducing actions regardless of their costs. Such approach allows one to assess the actions taken by the international community concerning WMD non-proliferation in a much wider context. This justifies the "deep defence" principle, ${ }^{12}$ according to which no security measure is perfect, so actions must be diversified. It is the specific situation that influences the decision to apply political, diplomatic, legal, economic, information or military measures. It must also be stressed that their form and scope is different for each WMD type.

\section{The apocalyptic nature of nuclear weapon}

The discovery of nuclear weapon has undoubtedly had a significant impact on the history of the world. Used twice at wars and checked during nuclear tests, ${ }^{13}$ it still terrifies the human due to the unimaginable force of its destruction

${ }_{10}$ Relative numbers are quotients of absolute numbers describing interrelated phenomena. Relative numbers are widely used in statistical analysis, with special significance ascribed to those which characterise the intensity or structure of phenomena. See: T. Michalski: Statystyka. Podręcznik. Warszawa 2004, p. 87.

${ }^{11}$ Risk acceptability denotes a risk level which both individuals and the society are able to accept without specific risk management actions. The acceptable level is also related to tolerable risk, defined as a level which the society is able to accept as long as the risk is monitored and risk reduction actions are undertaken. A. KosIERADZKA, J. ZAWILA-Niedźwiecki: Zaawansowana metodyka oceny ryzyka..., p. 264-265.

${ }_{12}$ Zapobieganie stratom $w$ przemyśle. Red. A.S. Markowski. Cz. 3: Zarządzanie bezpieczeństwem procesowym. Łódź 2000, p. 191.

${ }_{13}$ A nuclear test means a single or at least two nuclear explosion(s) conducted at a test site within an area delineated by a circle having a diameter of $2 \mathrm{~km}$ within a total period of 0.1 second. Source: Protocol of 1990 to The Treaty on the Limitation of Underground Nuclear Weapon Tests - Threshold Test Ban Treaty (TTBT) of 1974. 
factors. It is estimated that approx. 2,050 nuclear weapon tests ${ }^{14}$ have been conducted worldwide in the atmosphere, underground and underwater. The effects of using nuclear weapon, without distinguishing between military and civilian targets, may occur immediately even in the areas situated far away from the detonation location. They include a shock wave, ionising radiation and thermal radiation. However, the delayed action of such weapon (from several hours to decades) takes the form of radioactive fallout which contains radioactive substances formed during an explosion (approx. 200 isotopes of 35 elements). Sample calculations showing the effects of a hypothetical nuclear load application are presented in the next part of the article, in Fig. 2.

Nuclear weapon can be classified according to various criteria, the most important of which include:

- the number of stages and types of nuclear reactions: single-stage weapon (nuclear fission of the nuclei of heavy elements - uranium or plutonium), twostage weapon (fission and fusion of light elements) and three-stage weapon (works according to the following scheme: fission - fusion - fission) ${ }^{15}$;

- load name (atomic, hydrogen, thermonuclear);

- purpose (strategic, tactical and operational, tactical);

- load power (very small, small, medium, big and very big).

Due to operational needs, especially the methodology of estimating the effects of a nuclear explosion, defining the load power is of fundamental importance. That value means the energy released via a nuclear explosion and is expressed using a TNT equivalent (units: kilo- or megatons). ${ }^{16}$ It constitutes the basic piece of information which characterises an explosion in military terms or a test explosion. Its determination allows one to conduct further calculations aimed at, among other things, forecasting the radioactive contamination zones, fires, casualties, infrastructure destruction etc. It can be established with measuring instruments such as seismic, hydroacoustic or infrasound stations ${ }^{17}$

${ }^{14}$ https://www.ctbto.org/nuclear-testing/history-of-nuclear-testing/types-of-nuclear-we apons-tests/(accessed: 2.05.2019).

IS Three-stage nuclear loads - they contain two different fissile materials and a material undergoing fusion. At the first stage of an explosion, Uranium-235 or plutonium undergoes fission. The released energy initiates the fusion of light elements which takes place at stage two. The high-energy neutrons emitted during that reaction cause the fission of Uranium-238 — that reaction takes place at the third explosion stage. These are sometimes referred to as "jacket loads" in Polish because Uranium-238 usually constitutes a shell (jacket) of three-stage loads (bombs, warheads).

${ }^{16}$ J. Kubowski: Broń jądrowa. Warszawa 2008, p. 22-23.

17 The abovementioned stations form the International Monitoring System provided for in the Comprehensive Nuclear-Test-Ban Treaty. Seismic stations can locate seismic incidents and distinguish between nuclear explosions and earthquakes. Hydroacoustic stations use highly sensitive microphones (acoustic sensors of pressure) to detect acoustic waves, including those caused by explosions, from a long distance. Infrasound stations detect sound waves of a very 
or laboratories recording the presence of selected radioactive elements in the atmosphere ${ }^{18}$ as well as based on the parameters of the radioactive cloud estimated by specialised observation posts.

The specificity of nuclear weapon has made it play a deterring role from the very beginning; this was especially visible during the Cold War. However, nuclear deterrence has been modified throughout the years to match the needs of the changing political and military situation. Consequently, it has evolved into the following subsequent strategies: "conventional forward defence and air counter-attack," "massive retaliation," "mutually assured destruction" and "elastic reaction" as well as their versions (Schlesinger's doctrine of limited nuclear options of 1974 and Presidential Directive 59 of 1980). ${ }^{19}$

low frequency in the atmosphere and can distinguish between nuclear explosions, volcanic eruptions and falling meteorites. See more in: A. Suda: Traktat o Całkowitym Zakazie Prób z Bronia Jadrowa - niedokończony rozdziat rozbrojenia nuklearnego. "Ekoatom" 2013, nr 9, p. 39.

${ }_{18}$ The presence of certain radioactive particles (e.g. Cs137, H3, C14, Sr90, I131) in the air constitutes irrefutable evidence of having conducted a nuclear explosion. $\mathrm{Cs}$ and $\mathrm{Sr}$ are particularly dangerous to people.

19 "Conventional forward defence and air counter-attack" (1950) was also called "the sword and the shield" and was the first strategy adopted by NATO. It assumed the use of the American nuclear weapon delivered by strategic aircraft (the sword) and the European conventional forces to ensure defence against a massive Russian attack (the shield). The "massive retaliation" strategy was developed by the then Secretary of State J.F. Dulles in 1954 and adopted by NATO three years later. It was a response to the increasing advantage of the Soviet Union in conventional forces. The strategy assumed the creation of a "nuclear umbrella" over the European NATO Member States to discourage the opposite party from aggression. The distribution of the American non-strategic nuclear weapon in Europe also began at that time. The "mutual assured destruction" (MAD) theory of 1964 was the basis for the defensive doctrines from the Cold War period. Its assumptions were based on the balance of power and the belief that the use of nuclear weapon by one party to the conflict would trigger a retaliation strike with disastrous effects. The "elastic reaction" strategy was developed in 1967 by the then Secretary of State R. McNamara. It treated the conventional forces as the main defence asset, while nuclear weapon was seen as a supporting element. The elastic use of nuclear weapon had two meanings. First, to minimise casualties among civilians, it was planned to attack only the enemy's selected nuclear facilities (systems). Second, nuclear planning demonstrated clear-cut phases: controlled nuclear escalation aimed at forcing a stop to the fights and then a massive nuclear attack (both strategic and non-strategic). In 1974, the North Atlantic Alliance acknowledged the role of French and British nuclear forces in nuclear deterrence. Schlesinger's doctrine was developed in the same year. Its main assumptions come down to signalling the readiness for further escalation and strategic support for collective defence in Europe. Presidential Directive 59 broadened the range of selective attacks (to include i.a. political targets) and assumed an expansion of the commanding systems and new combat assets, such as MX and Trident II ballistic missiles, self-controlled missiles launched from the aircraft and B-2 bombers. A. KACPRZYK: Polityka jadrowa USA a odstraszanie w Europie, notatki z wyktadu. War Studies University, 11 April 2018. Unpublished material. 
In the 1990s and at the beginning of the 21st century, nuclear weapon lost some of its significance as a retaliation-based deterrence factor. The administration of G.W. Bush made it play a smaller role and emphasized the integration of nuclear forces with conventional offensive assets as well as nuclear arsenal elasticity. It was allowed to use nuclear weapon only against a country which attacked the United States territory with any weapon of mass destruction. The North Atlantic Alliance also reckoned that the hazard of a conflict requiring a military response had diminished. Throughout that period, numerous countries intensified their effort to enter the Alliance. The hazard which commenced the strategic discourse at that time and is still present there is nuclear proliferation and rocket missile technology development. This was accompanied by President Bush labelling Iraq, Iran and North Korea as "the axis of evil" in 2002.

\section{The contemporary conditions of nuclear deterrence}

It was not predicted at the beginning of the present decade that its end would see a specific renaissance of nuclear weapon and a return to nuclear deterrence. The Global Zero option ${ }^{20}$ did not seem probable, but the new nuclear policy by President B. Obama announced in April 2010 was perceived as a long-term effort to eliminate this weapon category. It was planned to diminish further the significance of nuclear arsenals in comparison with the previous strategy pursued by President Bush, while conventional forces were supposed to gain more importance. Obama's administration limited the possibility of conducting a nuclear strike only to the states which owned this kind of weapon. It was simultaneously declared that no new technologies of building nuclear resources would be developed. ${ }^{21}$

The adoption of that strategy coincided with the signing of New START (Treaty on Measures for the Reduction and Limitation of Strategic Offensive Arms) in Prague. The treaty was signed on 9 April 2010 by Presidents B. Obama and D. Medvedev and replaced the previous treaty, START I, ${ }^{22}$ which had ex-

20 The term is the name of an organisation founded in December 2008, which aims at the worldwide elimination of nuclear weapon. See more - https://www.globalzero.org/about-us/ our-mission/(accessed: 2.05.2019).

National Security Strategy 2010 - http://nssarchive.us/NSSR/2010.pdf p. 23 (accessed: 2.05.2019).

22 New START was preceded by the following treaties: Start I (Strategic Arms Reduction Treaty), signed on 31 July 1991 , which expired on 5 December 2009, Start II, signed on 3 January 1993 (it did not enter into force because the Russian parliament did not ratify it) and SORT (Strategic Offensive Reductions Treaty), signed on 24 May 2002, under which 
pired five months earlier. The parties decided that, within seven years, each of them would reduce the number of nuclear warheads to $1,550^{23}$ pieces distributed $^{24}$ on selected delivery means - intercontinental ballistic missiles (ICBM), submarine-launched ballistic missiles (SLBM) and heavy bombers ${ }^{25}$ adapted to deliver nuclear weapon. The delivery means themselves were limited to 800 pieces of equipment, including 700 so-called distributed pieces remaining fully ready to use. When one remembers that those arms categories were reduced in comparison with the SORT and START I treaties by $30 \%$ and $70 \%$ respectively, one understands the generally favourable comments accompanying the signing of New START. The press reports of the time announced a historical event, a milestone on the way to the world without nuclear weapons, a breakthrough in mutual trust and the conscious responsibility of both nuclear superpowers.

The signing of the treaty was of great political significance to both parties. The United States perceived it as an important step within "resetting" the relations with Russia, while the latter viewed the negotiations and their positive result as a confirmation of its own prestige and its status of an equal partner of the USA. ${ }^{26}$ The political context was additionally strengthened by the verification mechanisms aimed at building trust. The most important of them assumed an exchange of telemetric data on test flights of new rocket missiles, inspections in the bases where the weapons governed by the treaty were distributed and giving special identification labels to mobile missile launch systems. The treaty was adopted as binding for ten years (till 2021) and can be extended by five years.

The seven-year period of strategic nuclear weapon reduction as declared by both states expired in 2018. Therefore, it is suitable to sum up the treaty effects and analyse the obtained results.

the number of nuclear warheads was to be reduced to $1700-2200$ pieces for either party till 31 December 2012. SORT also confirmed the validity of START I.

${ }^{23}$ The Treaty Between The United States of America and the Russian Federation on Measures for the Further Reduction and Limitation of Strategic Offensive Arms, art. II, par. 1.

${ }^{24}$ Distributed warheads are those installed on delivery means or located in the bases where operationally ready nuclear forces are stationed.

${ }^{25}$ A heavy bomber is one which has a range exceeding eight thousand $\mathrm{km}$ and/or is equipped with a nuclear long-range strategic air-launched cruise missile (ALCM). It is interesting that the parties defined a heavy bomber for nuclear weapon verification purposes as a bomber carrying one load regardless of its real capabilities. Source: Protocol to the Treaty Between The United States of America and the Russian Federation on Measures for the Further Reduction and Limitation of Strategic Offensive Arms, Part One.

${ }^{26}$ Z. LACHOWSKI: Nuklearne rozbrojenie i nieproliferacja: geneza, stan i perspektywy. “Bezpieczeństwo Narodowe" 2012, nr 22, II, p. 72. 
Strategic nuclear weapon reduction under New START

\begin{tabular}{|l|c|c|c|c|c|c|}
\hline & \multicolumn{3}{|c|}{2011} & \multicolumn{3}{c|}{2019} \\
\cline { 2 - 7 } & $\begin{array}{c}\text { Distributed: } \\
\text { ICBM, SLBM, } \\
\text { heavy bombers }\end{array}$ & $\begin{array}{c}\text { Total: ICBM, } \\
\text { SLBM, heavy } \\
\text { bombers }\end{array}$ & Warheads & $\begin{array}{c}\text { Distributed: } \\
\text { ICBM, SLBM, } \\
\text { heavy bombers }\end{array}$ & $\begin{array}{c}\text { Total: ICBM, } \\
\text { SLBM, heavy } \\
\text { bombers }\end{array}$ & Warheads \\
\hline The USA & 882 & 1,124 & 1,800 & 656 & 800 & 1,365 \\
\hline Russia & 521 & 865 & 1,537 & 524 & 760 & 1,461 \\
\hline
\end{tabular}

Developed by the author.

Source: US Department of State, Bureau of Arms Control, Verification and Compliance: February 2011, March $2019^{27}$.

The presented data show that the United States and Russia fulfilled the obligations they had assumed. However, New START concerned only a part of the strategic nuclear arsenal, albeit that was the key part for the bilateral negotiations. One should highlight that every ICBM can deliver several nuclear warheads, while the SLBM distributed on submarines are considered as the first-strike weapon owing to the element of surprise. Unfortunately, due to the limitations introduced in the treaty, the latter has not significantly affected the total amount of the nuclear weapon owned by both superpowers. According to the data of the Stockholm International Peace Research Institute, the United States still have 6,450 warheads at their disposal, including 1,750 operationally ready ones, while Russia owns 6,850 warheads, $1,600^{28}$ of which are operationally ready. The continued existence of such big arsenals (they jointly constitute $91 \%$ of the world's resources of strategic nuclear weapons) lets certain nuclear states, especially China, use this disproportion ${ }^{29}$ to marginalise the significance of their own nuclear weapons during disarmament talks.

Considering the significance of New START, one must underline that, till its expiration in 2021, it will be the only treaty ${ }^{30}$ between the United States and Russia allowing for information exchange regarding the amount of the strategic nuclear weapon owned by the two states. If New START is not extended, one can forecast that the negative effect will be the impossibility of data exchange between both states concerning the size, development and modernisation of their

${ }^{27}$ https://2009-2017.state.gov/t/avc/rls/164722.htm; https://www.state.gov/t/avc/newstart/ 290759.htm (accessed: 4.05.2019).

SIPRI Yearbook 2018 Armaments, Disarmament and International Security, p. 11.

29 The nuclear resources of the remaining countries (as of 2018): France - 300 warheads, China - 280, Great Britain - 215, India - 130 - 140, Pakistan - 140 - 150, Israel - 80, North Korea - 10-20. Ibidem.

${ }^{30}$ In February 2019, the United States and subsequently Russia commenced their withdrawal from the INF Treaty (Treaty on Intermediate-range Nuclear Forces), which imposes complete elimination of intermediate-range ballistic missiles. 
nuclear arsenals. One is also justified in fearing that, once the limitations stemming from the treaty are abolished, Russia will strive to increase the potential of its Strategic Nuclear Forces. The signs auguring this include i.a. plans of providing the army with additional RS-28 Sarmat intercontinental ballistic missiles which can deliver "Avangard" hypersonic systems as well as replacing the older RS-12M1 Topol-M missiles with modern ones - RS-24 Yars. ${ }^{31}$

Regardless of strategic arsenals, the significance of which gradually diminishes (predominantly due to the low probability of using nuclear loads with a big or very big power), the United States, Russia and the remaining nuclear states have tactical nuclear weapons (TNW) at their disposal. TNW parameters make it suitable for use during combat operations on a limited (tactical) scale. The significant properties in this case are: a limited range of $450-500 \mathrm{~km}$ and a relatively small power. This is clearly visible in comparison with thermonuclear weapons: the striking power of the latter is expressed in megatons and their tactical load of 15-20 kilotons is comparable with the bombs dropped on Hiroshima and Nagasaki. ${ }^{32}$

A combination of numerous factors has contributed to the increase in significance of this weapon category, which raises a growing number of concerns in Europe, especially the Baltic states and Poland. First, it must be stressed that tactical nuclear weapons have not been a subject of any disarmament treaty yet $^{33}$. Consequently, no official data exist regarding their real resources in various countries. Nevertheless, Russia is believed to be a TNW tycoon because it

${ }^{31}$ Information note of 6 June 2019 by the Defence Attaché in Moscow (this article does not state the planned quantities of the abovementioned armament types or the names of the army units supposed to receive this equipment). The Sarmat ballistic missile weighs approx. 100 tons and can deliver up to 16 combat warheads with a power of two megatons each to the distance of 18 thousand $\mathrm{km}$. The RS-24 Yars intercontinental ballistic missile can deliver up to six combat warheads with a power of 300 kilotons each to the distance of approx. II thousand km.

2 The classification of tactical nuclear weapons according to their load power is relative because the value bracket is very diversified, ranging from less than one kiloton to as many as $50 \mathrm{kt}$. Russia's Raduga Kh-22 missiles are adapted to deliver warheads of $1 \mathrm{Mt}$, which exceeds the "norms" for TNW many times.

${ }^{33}$ Attempts to regulate the TNW issue are known as Presidential Nuclear Initiatives (PNI), which were informal unilateral actions taken in 1992. President of the USA G. Bush Senior and then President of the Soviet Union Mikhail Gorbachev obliged to have their respective countries destroy significant amounts of the TNW stockpiled in their arsenals. However, those initiatives had no verification mechanisms, so it is hard to determine nowadays whether all of their obligations have been fulfilled and how many pieces of such weapons remain at the disposal of both states. The TNW negotiation attempts made by the administration of B. Obama in June 2013 also failed because Russia conditioned commencing the talks on meeting a number of conditions unacceptable to the United States, i.a. complete withdrawal of American B-61 nuclear bombs from Europe, giving up the construction of the Ballistic Missile Defence in the Central and Eastern Europe and including the nuclear potential of Great Britain in the negotiations. 
traditionally perceives tactical nuclear weapons as a way of counterbalancing the economic, scientific and technological advantage of the United States and the North Atlantic Alliance Member States. Russia is estimated to possess approx. two thousand non-strategic warheads allocated to the individual types of its armed forces. ${ }^{34}$ An additional trump card of Moscow is the wide series of delivery means which includes mobile missile launch systems, artillery, aircraft, torpedoes, depth charges and mines. The difficulties in determining the number of the Russian systems which deliver non-strategic nuclear weapons stem i.a. from their dual use. Most of those systems lack the characteristic external features which allow the experts to distinguish between conventional and nuclear variants.

Russian tactical nuclear weapons are constantly modernised in order to increase their CEP and range with a simultaneous reduction of their manufacturing and operation $\operatorname{costs}^{35}$. This is clearly disproportionate to the amount of the American non-strategic nuclear weapons distributed in Europe. It is worth reminding that, after withdrawing selected armament systems from the continent in the 1990s, the resources are estimated to reach approx. 150 pieces. These include B-61 gravity bombs with adjustable power (approx. 0.3 to 150 kilotons) distributed in five NATO Member States: Belgium, the Netherlands, Germany, Turkey and Italy. When analysing the risk posed by the contemporary tactical nuclear weapon, one must consider not only its amount, but also, or maybe first and foremost, the role it plays in the military doctrines of the states which have it at their disposal, especially Russia and the United States.

The provisions on nuclear weapons included in the binding military doctrine of the Russian Federation of December 2014 coincide with the relevant views expressed in the previous doctrine (2010). The current doctrine states that "[prevention] of a nuclear military conflict ... is the basis of the military policy of the Russian Federation". Nonetheless, the main tasks in the scope of deterring and preventing military conflicts include maintaining "the nuclear deterrence potential at a sufficient level." ${ }^{36}$ Moreover, "[the] Russian Federation shall reserve the right to use nuclear weapons in response to the use of nuclear and other types of weapons of mass destruction against it and/or its allies, as well as in the event of

${ }^{34}$ The probable allocation of TNW to the types of the armed forces is as follows: air force: approx. 730 loads delivered by suitably adapted planes (Tu-22M3 Backfire-C, Su-24M Fencer, Su-34 Fullback, Su-25 Frogfoot and Su-30 Flanker-C); navy: approx. 700 loads (rocket missiles, rocket-assisted torpedoes, torpedoes and depth charges) distributed on submarines and surface combatants; air defence forces: approx. 430 loads (ground-to-air missile systems, antiballistic systems); land forces: approx. 170 loads delivered by mobile missile launch systems - SS-21 Scarab (Tochka) and SS-26 Stone (Iskander).

${ }^{35}$ Note of 19 June 2019 by the Defence Attaché in Washington.

${ }_{36}$ The military doctrine of the Russian Federation, clause 20 and $21 \mathrm{c}$ - https://web.ar chive.org/web/20150721195150/ (accessed: 28.05.2019); http://www.rusemb.org.uk/press/2029 (accessed: 28.05.2019). 
aggression against the Russian Federation with the use of conventional weapons when the very existence of the state is in jeopardy." ${ }^{37}$ The unsettling aspect here is both the mere possibility of using nuclear weapons in conventional combat operations - an act of this kind would completely change the nature of a conflict - and the unclear definition of the circumstances authorising such a decision, which is a prerogative of the President of the Russian Federation.

When the conflict in Ukraine began, the Russian nuclear threats intensified. They were intended to underline that in case attempts were made to return Crimea to Ukraine by force, Russia possessed diversified and effective retaliation assets and tactical nuclear weapons played a significant role among them. This narrative is visible in the statements of the persons holding key political and military positions, i.a. President Vladimir Putin ${ }^{38}$ and Chief of the General Staff of the Armed Forces of Russia Valery Gerasimov. ${ }^{39}$

A manifestation of this nuclear determination is so-called de-escalation nuclear strike scenario. It has not been officially confirmed, but the mere presumptions emerging in relation to it have aroused a feeling of uncertainty in the world. It is believed, among other things, that Russia may decide to detonate a tactical nuclear load in the territory of a state which does not possess a nuclear arsenal. This would take place at the initial stage of a conflict. Taking into account the geographical location of Poland and the current political and military conditions, the hazard for that country is obvious. The aim of such an attack would be to discourage the NATO Member States, especially Western Europe, from supporting their attacked ally, and therefore to end the conflict on the conditions imposed by Moscow. From the Russian point of view, this would be a specific "de-escalation."

It is also highly probable that Russia practised the use of various nuclear weapon delivery means and even mock attacks on targets located in enemy territory during the cyclically held Zapad military exercise (2013, 2017). European capital cities, beginning with Warsaw and Vilnius, are listed in this context (an attack on Warsaw is visualised in Fig. 2). Experts also mention facilities of strategic importance in Sweden.

37 Ibidem, clause 27.

38 For example, in August 2014 in Yalta, Putin announced that he would soon "surprise the West with ... new developments in offensive nuclear weapons". At a meeting with young people the same month, he stressed that Russia "was strengthening its military and nuclear potential" and that "Russia was one of the most powerful nuclear states" — https://www. tvp.info/16832858/putin-testuje-rakiete-i-straszy-bronia-atomowa-nuklearny-atak-mozliwyekspert-w-zasadzie-tak (accessed: 2.06.2019).

3 In December 2016, during a meeting with the military attachés accredited to Russia, General Valery Gerasimov stated that in 2016, "the main efforts of the Ministry of Defence focused on maintaining the nuclear potential" - https://www.tvn24.pl/wiadomosci-zeswiata,2/rosja-armia-poswieci-szczegolna-uwage-strategicznej-broni-jadrowej,700059.htm (accessed: 2.06.2019). 


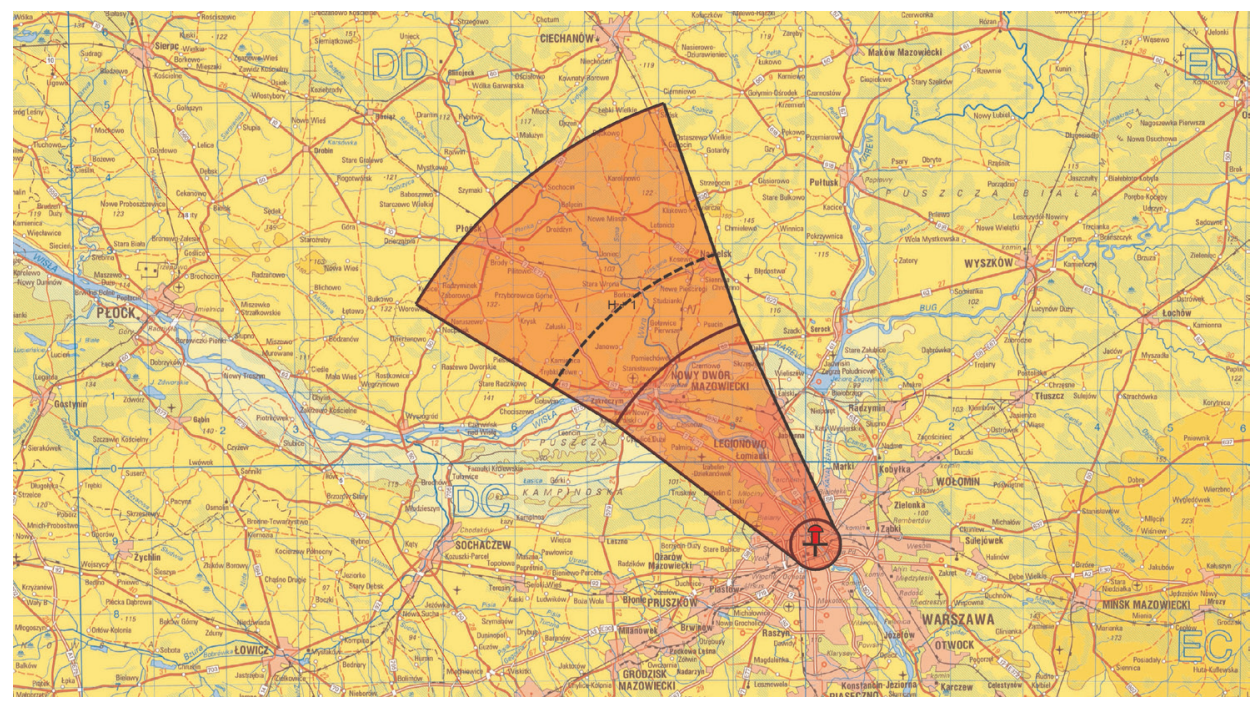

Fig. 2. The forecast contamination after a hypothetical nuclear strike on Warsaw.

Developed by the author using "Promień" — an electronic contamination forecasting and assessment system. Map scale: 1: 500 thousand.

Assumptions: explosion site (ground zero) - the Ślasko-Dabrowski bridge, load power - 20 kilotons, averaged wind direction in the upper layers of the atmosphere - 320 degrees, effective wind speed $42 \mathrm{~km} / \mathrm{h}$.

The calculations show that the most tragic effects of the attack would take place inside a virtual circle with a radius of approx. $3.4 \mathrm{~km}$ and ground zero as the centre. It is predicted that over $90 \%$ of the population present in the area would be harmed at the moment of the attack, $43 \%$ of whom would die; further deaths would take place within the first six months and later. ${ }^{40}$ Taking into account that the average population density in the city centre (Śródmieście district - the explosion site) is 7,515 people per $\mathrm{km}^{2}$, i.e. nearly two times higher than the Warsaw average $(3,412$ people per $\mathrm{km} 2){ }^{41}$ the only possible conclusion is that the attack would cause a humanitarian disaster requiring international help.

One must also stress that buildings in the area, including those with reinforced concrete structures, would be destroyed or damaged and their collapsed remnants would create continuous or local obstacles to the rescue service equipment. A separate hazard would be posed by spot and area fires (second- and third-degree burns of the human body) as well as destruction of heating devices and power and gas supply systems.

${ }^{40}$ Calculation basis: Metodyki prognozowania $i$ oceny strat $w$ rejonach uderzeń jądrowych. Warszawa 1991, p. 21-23 and 70-71.

${ }^{41}$ „Przegląd Statystyczny Warszawy” 2018, nr 1, table 6, p. 39. 
Another parameter characterising a nuclear explosion is ionising radiation and radioactive fallout which spreads downwind, thus causing radioactive contamination in the area situated far away from the epicentre. In the analysed example, two contamination zones would be formed: zone I $-32 \mathrm{~km}$, zone II $-64 \mathrm{~km} .{ }^{42}$ Their shape is presented in the figure.

The current stance of the United States on nuclear issues ${ }^{43}$ was published in Nuclear Posture Review (NPR) in February 2018. The significance of NPR is proved by its publishing in the initial period of the term of office served by a new president. The document contains the most important arrangements concerning the nuclear policy of the United States, including the nuclear weapon use strategy and arsenal modernisation plans.

In NPR 2018, the administration of Donald Trump states that returning to the idea of nuclear deterrence in the scope adequate to diagnosed hazards is the priority. The greatest hazards indicated in the document are: the readiness manifested by Russia to use non-strategic nuclear weapons at the initial stage of a conflict and Russian expansion and modernisation programmes concerning delivery means. ${ }^{44}$ The changes in NPR 2018 are also justified with lack of transparency in the nuclear policy of China, which "possesses nuclear warheads... and nuclear-armed, theatre-range ballistic missiles capable of reaching [US] territory, allies, partners, forces, and bases in the region." ${ }^{\text {45 }}$ The document also highlights the increasing activity of Chinese army in the area of South China Sea and the territorial claims of that superpower toward its neighbours. The Central State is accused of conducting secret nuclear tests of loads with a small and very small power and probably (author's note) "having implemented a programme of fast expansion and diversification of the nuclear arsenal, allowing it to double its resources of this weapon during the next decade." ${ }^{36}$

Another state mentioned in the NPR is North Korea, the armament policy of which has raised justified concerns in recent years. One should recall the accel-

${ }^{42}$ Unprotected persons exposed to ionising radiation in zone I may absorb a dose equal to or exceeding $150 \mathrm{cGy}$ in less than four hours of the moment they are reached by the radioactive fallout. The total dose absorbed by unprotected persons exposed to the radiation in zone II should not exceed $150 \mathrm{cGy}$ in the first four hours of the moment they are reached by the radioactive fallout; it is simultaneously assumed that the dose would exceed 50 cGy within 24 hours. Persons staying outside zone I and II may absorb a radiation dose not exceeding $50 \mathrm{cGy}$ within 24 hours of the moment they are reached by the cloud; the total dose till the radiation fades would not exceed $150 \mathrm{cGy}$. Source: Metodyka oceny sytuacji skażeń chemicznych, biologicznych i promieniotwórczych. Warszawa 2013, p. 200.

${ }^{43}$ The previous Nuclear Posture Review of 2010, drafted by the administration of B. Obama, is mentioned on page 8 of this article.

${ }^{44}$ https://media.defense.gov/2018/Feb/02/2001872886/-1/-1/1/2018-NUCLEAR-POSTU RE-REVIEW-FINAL-REPORT.PDF (accessed: 14.06.2019).

45 Ibidem, p. 31-32.

${ }^{46}$ Information note of 4 June 2019 by the Defence Attaché in India, New Delhi, p. 1. 
eration of its nuclear programme and the fiasco of the meetings between Trump and Kim Jong Un concerning i.a. denuclearisation of the Korean Peninsula (June 2018, February 2019). An equally significant hazard to international security is still posed by Iran, against which the United States restored economic sanctions in May 2019. ${ }^{47}$ The dynamics of the events concerning the Iranian nuclear programme manifest itself in the fact that on 7 July 2019, Iran announced returning to uranium enrichment above the $3.67 \%$ threshold defined in the Joint Comprehensive Plan of Action of 14 July 2015.

Nuclear Posture Review has the nature of a doctrine and contains the official stance of the American administration on the possible use of the nuclear arsenal. Like the previous reviews, NPR 2018 confirms the principle of "no first use" against the countries which do not possess nuclear weapons and have ratified the Nuclear Non-Proliferation Treaty (NPT) and observe its provisions. At the same time, it permits using nuclear weapons in response to attacks with chemical and biological weapons as well as, which is a novelty in the NPR, cyberattacks aiming at the US nuclear systems, critical infrastructure, commanding systems etc. That clause broadens the scope of the possible nuclear response in comparison with NPR 2010, which excluded such possibility. It refers to the assumptions of G. Bush's nuclear doctrine of 2002, which was dominated by the prevention of and defence against terrorist attacks, including chemical and biological ones. The NPR from that period indicated the states belonging to "the axis of evil" (Iraq, Iran, North Korea, Syria and Libya) as potential targets of an American nuclear attack. It also allowed for the use of small-power nuclear loads to destroy underground bunkers and fortified depots of biological and chemical weapons.

The 2018 Review announces the planned modernisation of all the nuclear triad elements: ICBM, heavy bombers and SLBM-delivering submarines. The modernisation is divided into stages. First, it is planned to reduce the warhead power in selected Trident II D-5 submarine-launched missiles to adjust them to tactical use. It is simultaneously assumed that new versions of F-35 and B-21 planes as well as nuclear-armed long-range stand-off (LRSO) cruise missiles integrated with them will be commissioned for use in the army in the middle of the 2020s. Moreover, long-term plans (7-10 years) provide for equipping US Navy again with sea-based self-controlled missiles.

Analysing the contemporary conditions of nuclear deterrence requires presenting the stance of the North Atlantic Alliance, which was most comprehensively expressed in the NATO Warsaw Summit Communiqué. The introductory part contains an assessment of contemporary hazards; a separate paragraph

${ }^{47}$ On 14 July 2015 in Vienna, the P5+1 (the USA, China, Russia, France, Great Britain and Germany) concluded a nuclear agreement with Iran, the Joint Comprehensive Plan of Action (JCPOA), after 12 years of negotiations. Iran obliged to stop the works on its nuclear programme in exchange for the abolition of economic sanctions. 
(clause 10) is devoted to "Russia's destabilising actions and policies," which include i.a. "its irresponsible and aggressive nuclear rhetoric." ${ }^{\text {" }}$ "The strategic goal of the Alliance defined in the Communiqué is the strengthening of deterrence and defence "based on an appropriate mix of nuclear, conventional, and missile defence capabilities." A combination of these elements should counterbalance the arsenals of potential enemies. The document unambiguously states that "[as] long as nuclear weapons exist, NATO will remain a nuclear alliance." ${ }^{, 49}$

\section{Implications of WMD proliferation for international relations}

In the present decade of the 21st century, proliferation is considered first and foremost in the context of the actions taken by selected states and organisations (i.a. terrorist ones) in order to acquire WMD or the technologies and components necessary for its manufacture.

A possible way of applying the acquired assets would be a CBRN terrorist attack: chemical (chemical terrorism), biological (biological terrorism), radiological or nuclear, the latter also referred to as superterrorism, grand terrorism or catastrophic terrorism in order to highlight the effect of a hypothetical attack, which would reach hundreds of casualties (or more) in certain conditions. Depending on the target of an attack and the manner of its conducting, CBRN terrorism variants also include agriterrorism, which destroys agricultural crops, and zooterrorism, which causes losses of farm animals. ${ }^{50}$ Both types result in significant losses suffered by the economy of an attacked state.

The most spectacular act of CBRN terrorism was conducted in 1995 in the Tokyo underground by a Japanese sect called Aum Shinrikyō (Supreme Truth): 12 people died and approx. 5,500 were harmed, including approx. 50 severely harmed. After that event, counteracting the hazards of this type became the top priority.

One must underline that $\mathrm{CBRN}$ assets constitute a very dangerous weapon of diversified action when used by the perpetrators. They allow the attackers to manifest their ruthlessness and cause fear, dread and multi-faceted psychological effects among victims. The list of operational advantages is completed by the

48 Warsaw Summit Communiqué Issued by the Heads of State and Government participating in the meeting of the North Atlantic Council in Warsaw 8-9 July 2016, p. 3.

49 Ibidem, p. 12.

50 The list of the most hazardous biological agents contains 18 animal and 19 plant pathogens, including the bird flu virus, the classical swine fever (CSF) virus and the cattle plague virus. See more in: B. Michailiuk: Broń biologiczna jako zagrożenie bezpieczeństwa państwa. Warszawa 2015, p. 330-332. 
possibility of surprise (a hidden attack) and difficulties in detecting, identifying and proving an act of terror; this concerns especially bioterrorism. ${ }^{51}$

The WMD proliferation problem is in the centre of attention of the United Nations, the European Union, ${ }^{52}$ numerous international authorities, individual states and groups of states, i.a. the Visegrad Group. ${ }^{53}$

WMD proliferation, development and research has been criticised by Vatican many times. During a conference entitled "Perspectives for a World Free from Nuclear Weapons and for Integral Disarmament," held in November 2017, Pope Francis underlined, "International relations cannot be dominated by military strength [or] mutual intimidation... Weapons of mass destruction, particularly atomic, create nothing more than a false sense of security and cannot constitute the basis of peaceful coexistence between members of the human family." ${ }^{4}$

President of the Republic of Poland Andrzej Duda referred three times to the proliferation of WMD, especially chemical and nuclear weapons, during his speeches at the UN Security Council in January, May and September 2018. The President considered counteracting that hazard "as an important element of the

${ }^{51}$ See more in: W. WĄTOR: Terroryzm CBRN - wyzwanie dla stużb i administracji publicznej. W: Wyzwania i zagrożenia dla bezpieczeństwa międzynarodowego i narodowego pod koniec drugiej dekady XXI wieku. Red. K. CzorniK, M. Szynol. Katowice 2017, p. 219-245, and W. WĄTOR: Przeciwdziatanie terroryzmowi CBRN w świetle prawa polskiego. W: Zarzadzanie kryzysowe w aspekcie zagrożeń terrorystycznych. Red. B. MichaILIUK, J. Solarz, J. Stempień. Warszawa 2019, p. 213-232.

52 The EU stance on proliferation is included in the EU Strategy Against Proliferation of Weapons of Mass Destruction issued in December 2003. In December 2008, the EU adopted a new document entitled New Lines of Action by the European Union in Combating the Proliferation of WMD. It aims at facilitating operational cooperation in combating the proliferation of WMD by: (a) turning non-proliferation into a cross-cutting priority of EU and the Member States' policies; (b) identifying the existing best practice of combating the proliferation to encourage the spread of such practice in the Member States; (c) encouraging better coordination of the Member States' national policies and of existing EU tools and policies; (d) identifying the areas where EU action must be stepped up. - https://www.msz. gov.pl/pl/polityka_zagraniczna/polityka_bezpieczenstwa/nieproliferacja_bron1_masowego _ razenia/najwazn1ejsze_porozumien1a_1_1nicjatywy_z_zakresu_nieproliferacj1_1_rozbroje n1a_bmr/ (accessed: 17.06.2019).

An example of such action was the strategic workshop of the Visegrad Group states in 2013. In one of its thematic blocks, entitled "Security environment in the perspective of $10-15$ years", the proliferation of WMD and its delivery means was acknowledged as one of the main hazards. "Responsibility for a Strong NATO", a declaration of the Visegrad Group of 18 April 2012, indicates CBRN (chemical, biological, radiological and nuclear) defence as one of the projects enabling so-called smart defence. See more in: R. KupIECKI: Visegrad Defence Cooperation: From Mutual Support to Strengthening NATO and the EU. A Polish Perspective. Report No. 35. Centre for European Policy, 2013, p. 4-6, DAV4 Full Report. Towards A Deeper Visegrad Defence Partnership, Central European Policy Institute, 2012, p. $10-13$.

${ }^{54}$ https://www.romereports.com/en/2017/11/10/pope-francis-on-nuclear-arms-internatio nal-relations-cannot-be-dominated-by-military-strength/ (accessed: 16.06.2019). 
Polish security policy." ${ }^{55}$ Referring to the gas attacks in Syria and the attempt at murdering S. Skripal in Great Britain, the President stated, "Every use of a chemical weapon is a crime. It does not matter whether it is used on a mass scale by non-democratic regimes against their own peoples... or during an act of national terrorism. ${ }^{56}$ Concerning nuclear weapon proliferation, the President stressed its negative impact on the security level in the Central and Eastern Europe. ${ }^{57}$

Poland's increased activity concerning proliferation prevention is related to its term of office as a non-permanent member of the UN Security Council in 2018-2019. Poland's involvement was also visible last year when it chaired the works of the Preparatory Committee to the 2020 Nuclear Non-Proliferation Treaty Review Conference as well as the sessions of the International Code of Conduct against Ballistic Missile Proliferation (the Hague Code of Conduct, $\mathrm{HCOC}$ ).

The basis for combating the proliferation is international agreements devoted to individual WMD types. They demonstrate significant diversification, from the genesis of their conclusion, ${ }^{58}$ via their purpose, the obligations of the signing states and the control and verification mechanisms included, to their effectiveness. They also vary in their universality indicators, expressed as the number of states which have signed and ratified a given agreement or remain beyond them (table 2).

${ }^{55}$ Speech of the President of the Republic of Poland during a High-Level Debate of the UN Security Council on 17 May 2018 - https://www.prezydent.pl/aktualnosci/wypowie dzi-prezydenta-rp/wystapienia/art,420,wystapienie-prezydenta-rp-andrzeja-dudy-podczasdebaty-wysokiego-szczebla-rady-bezpieczenstwa-onz.html (accessed: 16.06.2019).

Speech of the President of the Republic of Poland at a meeting of the UN Security Council on 26 September 2018 - https://www.prezydent.pl/aktualnosci/wypowiedzi-prezyden ta-rp/wystapienia/art,531,wystapienie-podczas-posiedzenia-rady-bezpieczenstwa-onz.html (accessed: 16.06.2019).

${ }^{57}$ This is confirmed by the following speech fragment: "Within the last few years alone, we have witnessed an evident breach of the Budapest Memorandum, which guaranteed the territorial integrity of Ukraine in exchange for a peaceful and voluntary denuclearisation of that country. We have also heard of using nuclear weapons to end conventional conflicts. The distribution of dual-use assets and technologies close to our borders has been equally alarming. All those actions have significantly contributed to a deterioration of the security environment". Ibidem.

58 The first regulations in international law concern biological and chemical weapons. One should note that, on 17 June 1925, on the initiative of the head of Polish delegation, Gen. Kazimierz Sosnkowski, the Geneva Protocol for the Prohibition of the Use in War of Asphyxiating, Poisonous or Other Gases was broadened to include bacteriological methods of warfare. 
The legal status of WMD agreements in selected countries ${ }^{59}$

\begin{tabular}{|c|c|c|c|c|c|c|}
\hline & & $\begin{array}{l}\text { The CWC } \\
\text { Convention }\end{array}$ & $\begin{array}{l}\text { The BTWC } \\
\text { Convention }\end{array}$ & The NPT Treaty & The CTBT Treaty & $\begin{array}{c}\text { The TPNW } \\
\text { Treaty }\end{array}$ \\
\hline \multirow{5}{*}{ 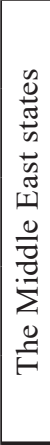 } & $\begin{array}{l}\text { Saudi } \\
\text { Arabia }\end{array}$ & signed, ratified & signed, ratified & signed, ratified & not signed & \multirow{5}{*}{$\begin{array}{c}\text { not } \\
\text { signed }\end{array}$} \\
\hline & Egypt & not signed & $\begin{array}{l}\text { signed, not } \\
\text { ratified }\end{array}$ & signed, ratified & signed, ratified & \\
\hline & Iran & signed, ratified & signed, ratified & signed, ratified & $\begin{array}{l}\text { signed, not } \\
\text { ratified }\end{array}$ & \\
\hline & Israel & $\begin{array}{l}\text { signed, not } \\
\text { ratified }\end{array}$ & not signed & not signed & $\begin{array}{l}\text { signed, not } \\
\text { ratified }\end{array}$ & \\
\hline & Syria & $\begin{array}{c}\text { signed, ratified } \\
\text { (2013) }\end{array}$ & $\begin{array}{l}\text { signed, not } \\
\text { ratified }\end{array}$ & signed, ratified & not signed & \\
\hline & India & signed, ratified & signed, ratified & not signed & not signed & \multirow{3}{*}{$\begin{array}{c}\text { not } \\
\text { signed }\end{array}$} \\
\hline & Pakistan & signed, ratified & signed, ratified & not signed & not signed & \\
\hline & $\begin{array}{l}\text { North } \\
\text { Korea }\end{array}$ & not signed & $\begin{array}{l}\text { signed, not } \\
\text { ratified }\end{array}$ & $\begin{array}{c}\text { denouncement } \\
\text { of the Treaty } \\
(2003)\end{array}$ & not signed & \\
\hline
\end{tabular}

Saerce: Developed by the author.

The table shows that the Middle East is the centre of the WMD proliferation problems. The elevated WMD-related risk in that region is indicated by the number of states which have not obliged to observe the abovementioned international agreements as well as the permanent inter-state and internal tensions. ${ }^{60}$ Despite the actions taken by the international community since the turn of the 1960s and 1970s, the Middle East has not become a WMD-free zone. Many signs show that it will be difficult to reach an agreement on establishing such a zone in the oncoming years, too.

When analysing the influence of WMD on the contemporary international relations, one should highlight the case of Syria. When the conflict commenced in 2011, Syria possessed over a thousand tons of toxic warfare agents (TWA) characterised by high toxicity: yperite, sarin and VX. As the fights escalated,

${ }^{59} \mathrm{CWC}$ - the Chemical Weapons Convention, BTWC - the Convention on the Prohibition of the Development, Production and Stockpiling of Bacteriological (Biological) and Toxin Weapons, NPT - the Non-Proliferation Treaty, CTBT - the Comprehensive NuclearTest-Ban Treaty, TPNW - Treaty on the Prohibition of Nuclear Weapons.

${ }^{60}$ According to a 2018 report by SIPRI, the main conflicts taking place in the Middle East and North Africa involve Egypt, Iraq, Israel, Libya, Syria, Turkey and Yemen. See the SIPRI Yearbook 2018..., p. 3. 
concerns emerged that a part of the TWA might be seized by Islamist groups and that the Syrian army could use chemical weapons to break the enemy's resistance.$^{61}$ In August 2012, B. Obama warned President Bashar al-Assad that the United States would react should he decide to conduct a chemical attack. The warning evoked associations with the situation preceding the 2003 intervention in Iraq, the pretext for which was the announced intention to destroy Saddam Hussein's alleged weapons of mass destruction.

In August 2013, the international community was shocked by the news of a gas attack in Damascus which killed approx. 1,400 civilians. Though alAssad's regime consistently denied having conducted that and the subsequent chemical attacks, ${ }^{62}$ the tragedy suffered by the victims and the pressure put by the international public opinion led to intense talks between the heads of diplomacy of the United States and Russia. They resulted in an agreement on the Syrian chemical weapons, concluded by both States on 14 September 2013 in Geneva. Under the agreement, Syria signed the Chemical Weapons Convention on the same month and its TWA resources were to be completely destroyed in 2014. Due to the complexity and costs of destroying such a big amount of highly toxic chemical substances, six countries participated in the destruction of the Syrian chemical weapons. The United States made available their special ship named "Cape Ray", on which TWA disposal took place for safety reasons. Germany ensured the destruction of several hundred tons of the hydrolysate generated by the yperite decomposition process. Great Britain, Finland, Denmark and Norway were responsible for the transport and neutralisation of selected chemical substances. ${ }^{63}$

The destruction of Syria's TWA, officially confirmed on 4 September 2014 by Sigrid Kaag, head of the mission of the Organisation for the Prohibition of Chemical Weapons, was not equivalent to excluding the possible application of other available chemical substances for military purposes. About a dozen gas attacks, which probably utilised chlorine ${ }^{64}$ were recorded in the years 2014

${ }^{61}$ See more in: M. Szybalski: Broń chemiczna w syryjskiej wojnie domowej 20112018. "Biuletyn CSOPBMR" 2018, nr 2(14), p. 2.

${ }^{62}$ Only two years after the attack, on 7 July 2015, did the UN Security Council pass a resolution aimed at determining the perpetrators who had used the chemical weapon in Syria in 2013. The USA, Great Britain and France blamed the Syrian army for the attack, while Russia, which supports al-Assad, highlighted that there was no irrefutable evidence of the government's blame available.

${ }^{63}$ S. KróL: Broń chemiczna w drugiej dekadzie XXI wieku. „Biuletyn CSOPBMR” 2016, nr 6(16), p. 3.

${ }^{64}$ Chlorine - a green-coloured gas which becomes yellow when liquefied. Its unpleasant, sharp scent is perceptible already at a 1:100,000 dilution ratio. It is applied in numerous syntheses of the chemical industry as well as a whitening agent in the textile and paper industries. It is also used to disinfect water and wastewater. It has a destructive action on metals, certain plastics, rubber and protective coatings. The mechanism of its toxic action consists 
2018. News agencies worldwide pointed at merely two such cases, of 7 April 2017 and 14 April 2018, mainly due to the retaliation strikes of the American, British and French forces at the Shayrat Airbase and selected Syrian scientific and military facilities.

The data presented in table 2, though limited to selected states, are representative and clearly demonstrate the difficulties in the WMD disarmament process.

Another unresolved problem is the nuclear test ban. The Comprehensive Nuclear-Test-Ban Treaty signed in 1996 has not entered into force yet. In order to become valid, it has to be ratified by the 44 states listed in Annex 2 to the Treaty which are capable of generating nuclear energy or possess research reactors. Consequently, though the Treaty has been signed by 184 states (and ratified by 168 states, including $36^{65}$ from the abovementioned group of 44 states), the lack of ratification i.a. by the states listed in the table prevents it from entering into force.

The identical stances of India and Pakistan toward the abovementioned agreements, including those concerning nuclear weapons, stem from the exceptional significance those two states have ascribed to this weapon category in mutual deterrence. The phenomenon in question dates back to 1988, when both countries nearly simultaneously conducted series of nuclear tests (India: five explosions $^{66}$ on 11 and 13 May, Pakistan: two to five explosions on 28 May and one explosion on 30 May), therefore joining the nuclear superpowers club. The nuclear weapon development programmes were, and still are, justified by the Kashmir conflict, which has lasted for over 70 years and caused three full-scale wars, a number of skirmishes and a serious test of strength in 1999, the latter entailing a hazard of a nuclear strike exchange.

The region around the Line of Control, which is seven hundred kilometres long and separates the armies of both parties, is one of the most heavily militarised places in the world due to the forces which station there (approx. 100 thousand soldiers of either party). Despite the official truce agreement of 2003, the Line of Control sees several dozen military incidents annually which may turn into an open conflict. The risk is increased by the activity of the Islamic separatist groups supported by Pakistan which have conducted a number of bomb attacks on the Indian military and civilian targets in recent years. The latest attack on an Indian military convoy, conducted by Islamic radicals from Jaish-

mainly in the creation of hydrogen chloride when gaseous chlorine comes into contact with moist mucous membranes and the skin, oxygen free radicals and other chlorine compounds exerting a strong biological action.

${ }^{65}$ https://wWw.ctbto.org/(accessed: 2.07.2019).

${ }^{66}$ The first Indian nuclear test was code-named "Smiling Buddha" and took place in May 1974 (a plutonium load with a power of $12-15 \mathrm{kT}$ or, according to American estimations, four to six kilotons). The subsequent Indian nuclear tests were conducted in 1988. 
e-Mohammed (Muhammad's Army), killed 40 soldiers and triggered air fights during which both armies shot down the enemy's planes.

When assessing the hazard stemming from India's and Pakistan's possession of nuclear weapons, one should underline several significant factors. First, their nuclear arsenals have been maintained on the same acceptable level for years (approx. 130 - 140 warheads in India and approx. 140-150 warheads in Pakistan ${ }^{67}$ to ensure so-called credible minimum deterrence. Second, there are doctrinal differences concerning nuclear weapon application. India has obliged not to use it first, but it will not hesitate to apply it in retaliation for the enemy's nuclear attack. Pakistan, the conventional potential of which is much smaller than that of its eastern neighbour, allows for a spoiling attack. Moreover, the decision-making cycle is very vaguely defined. Taking into account the role of the army in that country and the exceptional position of the chief commanders, one can assume that a decision to use nuclear weapons will be made within their circles. Third, the countries are neighbours, so a possible flight of a nuclear-warhead missile will last only several minutes, making the verification and warning systems of little use in such case. Moreover, the probable adjustment of the Pakistani tactical nuclear weapons to be delivered by Haft-9 short-range missiles (their range is approx. $60 \mathrm{~km}$ ), which are distributed close to the Line of Control, may confirm the existence of an option referred to as "use them or lose them." It permits launching a combat missile when it is threatened with seizure by an enemy conducting a fast-paced attack. This means a radical lowering of the decision-making threshold concerning missile use, probably to the level of tactical formation commanders.

The status of North Korea is symptomatic: it is the only country in the world which has not obliged to observe most WMD-related agreements (table 2). Beside its nuclear programme which attracts the public opinion's attention, North Korea is accused of not only possessing chemical and biological weapons, but also contributing to their dissemination. This information is hard to verify because the DPRK remains outside of the international agreements and therefore does not declare its resources or precursors to the manufacture of those weapons as well as refuses to undergo controls by specialised authorities. In such situation, all analyses are based on materials coming from satellite and electronic reconnaissance. However, their significance is limited because North Korea has obtained the operational masking capabilities and dispersed its secret research and manufacturing centres. Data verification via intelligence actions is practically impossible due to the incredibly elaborate control of the North Korean regime over the society.

Among the selected facts available, one must first and foremost highlight the murder of Kim Jong Nam, a stepbrother of the DPRK leader, carried out using

${ }^{67}$ SIPRI Yearbook 2018 Armaments, Disarmament and International Security, p. 11. 
a toxic warfare agent called VX at the Kuala Lumpur airport in February 2017. The United States blamed the government in Pyongyang for the assassination and toughened the sanctions imposed on North Korea. This was criticised by Russia, which underlined lack of proof of DPRK participation in the murder. Another significant event concerning the North Korean activity in the field of chemical weapons was the publishing of a United Nations report in February 2018. The document contains information about approx. 40 shipments of forbidden components used in chemical weapon production which the DPRK handed over to Syria in the years $2012-2017 .^{68}$

The presented examples confirm that the chemical weapon proliferation combating system, which receives the highest marks of all the WMD categories, must not be viewed as fully infallible. This also pertains to the protection of important facilities viewed as potential targets for a chemical attack (chemical terrorism). Places where huge numbers of people are present simultaneously and air circulation is forced (railway and underground stations, sports venues etc.) are particularly susceptible to this type of attacks. The abovementioned examples also prove how much attention the international community pays to every incident of using or trading in hazardous substances and how hard it is to prove such activity in a manner which raises no doubts.

The most recent nuclear weapon agreement is the Treaty on the Prohibition of Nuclear Weapons (TPNW), adopted on 7 July 2017 during the 72nd session of the United Nations General Assembly. The Treaty preamble particularly emphasizes the humanitarian, health-related, legal and environmental effects stemming from the presence of nuclear weapons in the world and their possible (including unintended) use. The adoption of the Treaty raises an analogy with the Humanitarian Impacts of Nuclear Weapons Initiative (the Humanitarian Initiative), which was announced during the NPT Preparatory Committee conferences in 2013 and 2014. It was supported by 155 countries, while five states objected the latter are the permanent members of the UN Security Council and possess nuclear weapons. The difficulties accompanying TPNW acceptance were signalled already by the voting results regarding a resolution by the UN Security Council on TNPW negotiations (December 2016). Though the resolution itself was eventually passed, as many as $30 \%$ of states voted against it or abstained from voting.

The controversy surrounding TPNW from the very beginning is well reflected by the voting result: 122 states voted for the Treaty, one (the Netherlands) voted against, one (Singapore) abstained from voting and 69 refused to vote. It is characteristic that the latter group included all the states possessing nuclear weapons and the North Atlantic Alliance Member States except the Netherlands (which voted against). One must add that TPNW has to be ratified by at least

${ }^{68} \mathrm{~h}$ https://www.wprost.pl/swiat/10107516/korea-polnocna-przekazywala-syrii-materialydo-tworzenia-broni-chemicznej-onz-opracowalo-raport.html (accessed: 4.07.2019). 
50 states to enter into force. Thus far, it has been ratified by only 13 states. The comprehensive obligation not to "develop, test, produce, manufacture, otherwise acquire, possess or stockpile nuclear weapons or other nuclear explosive devices" or to possess, transfer, use or threaten to use them ${ }^{69}$ is a truly lofty goal. What has prevented it from winning widespread approval? This question seems justified, especially because the nuclear weapon elimination idea is already 73 years old: the first resolution of the UN General Assembly on this matter was passed on 24 January 1946.

The lack of a compromise regarding the treaty may be justified in a simplifying manner by the different views of the individual countries, especially nuclear states, on the role of this weapon category in their own (or their allies') military doctrines and the current progress of the disarmament process. The stances of the United States, Russia and NATO Member States are crucial in this case. The United States, like Great Britain and France, believe that the vision of a world free from nuclear weapons is presently unrealistic. The most common argument cited to support this thesis is the nuclear programme development in North Korea. An alternative for the Treaty on the Prohibition of Nuclear Weapons is the involvement of the United States in advocating the Nuclear Non-Proliferation Treaty ${ }^{70}$ Russia believes that TPNW is "formulated one-sidedly and directed against it." ${ }^{\prime \prime 1}$ According to Russian Minister of Foreign Affairs Sergey Lavrov, "the possibility of a complete nuclear disarmament exists only on condition that all countries, including nuclear weapon owners, are provided with equal, indivisible and full-scope protection." ${ }^{2}$ The stance of the North Atlantic Alliance, presented in October 2017 by Secretary General J. Stoltenberg, comes down to a statement that "the Treaty on the Prohibition of Nuclear Weapons does not bring us closer to our goal - a world without nuclear weapons. It can actually threaten the progress we have made throughout the years in the field of nuclear disarmament and non-proliferation." 73 It is interesting that such an opinion was expressed directly after awarding the Nobel Peace Prize to an organisation named International Campaign to Abolish Nuclear Weapons (ICAN) ${ }^{74}$ The No-

69 Treaty on the Prohibition of Nuclear Weapons, art. 1 - http://www.icanw.org/wpcontent/uploads/2017/07/TPNW-English1.pdf(accessed: 12.07.2019).

Statement by UN Ambassador N. Haley of 27 March 2017 — https://www.polsatnews.pl/ wiadomosc/2017-03-27/rozmowy-onz-o-zakazie-broni-atomowej-bez-usa-w1elk1ej-brytan111-francj1/(accessed: 20.06.2019).

Statement by Russian Minister of Foreign Affairs Sergey Lavrov of 20 January 2018 https://zmianynaziemi.pl/wiadomosc/usa-buduje-nowe-bomby-atomowe-rosja-odmawia-pod pisania-traktatu-o-eliminacji-broni (accessed: 12.06.2019).

12 Ibidem.

73 https://www.tvp.info/34294949/szef-nato-z-rezerwa-o-traktacie-onz-o-zakazie-bronijadrowej-n1e-zbliza-nas-do-celu (accessed: 12.06.2019).

${ }^{4}$ ICAN is an association of non-governmental organisations conducting a campaign to support the actions aimed at a comprehensive ban on the possession, production and stockpil- 
bel Committee stated that the organisation had received the prize "for its work to draw attention to the catastrophic humanitarian consequences of any use of nuclear weapons and for its ground-breaking efforts to achieve a treaty-based prohibition of such weapons." 75

The most important cause of the limited results achieved by the activities concerning WMD proliferation prevention and elimination is the impossibility of conducting effective verification and control of the adherence to international agreements. The most elaborate control mechanisms concern the Convention on the Prohibition of the Development, Production, Stockpiling and Use of Chemical Weapons and on their Destruction, called the Chemical Weapons Convention. Their functioning is related to the activity of the Organisation for the Prohibition of Chemical Weapons (OPCW), which is the executive authority for the convention. Beside permanent supervision of the chemical weapon stockpile in the countries which have declared its possession as well as of the destruction of TWA and their production facilities, the OPCW monitors the industrial activity of the states which are parties to the convention regarding chemical compounds which could be used to manufacture chemical weapons.

On the contrary, the Convention on the Prohibition of the Development, Production and Stockpiling of Bacteriological (Biological) and Toxin Weapons and on their Destruction, referred to as the Biological Weapons Convention, does not offer control mechanisms to check whether the biological weapon production ban is observed, analogously to what OPCW does. This means that the parties are not obliged to declare their biological agents or toxins used in legal activities. At the same time, the convention permits research on the defence against biological agents, which complicates the verification of the adherence to its provisions. Many diseases are endemic, so research i.a. on the plague, anthrax or tularaemia may be justified and constitute a pretext for prohibited activities.

Regardless of the presented conditions, one should pay attention to selected operational features of biological weapons which are particularly important to terrorist organisations and states interested in their possession e.g. as an alterna-

ing of nuclear weapons. It includes over 460 partners from over a 100 countries. The organisation originated from the activity of International Physicians for the Prevention of Nuclear War (IPPNW) - an international association which established ICAN in 2006 at a congress in Helsinki. IPPNW was established in 1980, allegedly at the grass roots level, in order to prevent the hazards related to a nuclear war outbreak and strive to abolish this weapon altogether in the world. However, it is difficult to accept the association's goals and the motives behind its establishment with the passing of time, especially after taking into account the fact that one of its founders was Evgeny Chazov, $\mathrm{PhD}$, a scientist from the Soviet Union Cardiological University and a personal physician of the subsequent Soviet Union leaders: Brezhnev, Andropov and Chernenko. See more in: J. Wojciechowski: Pokojowy Nobel 2017 a broń jądrowa. "Biuletyn CSOPBMR" 2017, nr 4.

$75 \mathrm{https}: / / w w w . n e w s w e e k . p l / s w i a t / s p o l e c z e n s t w o /$ pokojowa-nagroda-nobla-2017-ican/ 2gzcych (accessed: 12.06.2019). 
tive to nuclear weapons or elaborate conventional forces of a potential enemy. Biological weapon production entails a certain risk, but it is easier, cheaper and faster than the production of other WMD types for a number of reasons. Another important factor is the great diversity of micro-organisms, which are classified as: bacteria, viruses, fungi (excluding mushrooms), algae and protozoa. ${ }^{76}$ The Appendix to the Polish Act of 5 December 2008 on the prevention and control of infections and infectious diseases in people ${ }^{77}$ includes 59 medical conditions and biological pathogens, while the list of the most dangerous pathogens according to NATO standards contains 15 micro-organisms and toxins.

The Non-Proliferation Treaty, which has been mentioned many times in this article and still constitutes the basis for the proliferation combating system regarding this weapon category, is implemented via NPT Review Conferences organised every five years. Due to the inalienable right to use nuclear energy for peaceful purposes (art. 4 of the NPT), the treaty entrusts the supervision of this activity to the International Atomic Energy Agency (IAEA). Still, one must remember that the remaining agreements listed in the article, the CTBT and the TPNW, have not entered into force. Consequently, the supervision and control procedures provided for in the agreements remain in the planning phase. ${ }^{78}$

Beside disarmament agreements, other important manifestations of the international community's activities to combat proliferation are so-called non-proliferation initiatives and export control regimes. Generally speaking, international regimes include sets of "principles, norms, rules and procedures concerning decision making which are characterised by convergent expectations of entities in a given field of international relations." ${ }^{79}$ These are less formal because they are not based on legally binding agreements. The purpose and scope of their impact is clearly defined since it stems from the hazard perception by the states participating in these initiatives.

The largest group (100 countries) belongs to the Proliferation Security Initiative (PSI), also called the Krakow Initiative because it was announced by President G. Bush at the Wawel Royal Castle in Krakow. It aims at preventing the smuggling of weapons of mass destruction and components used in its manufacture. The universality indicators of the remaining initiatives reach diversified values: $85 \%$ for the Global Initiative to Combat Nuclear Terrorism (GICNT)

${ }^{76}$ Podstawy mikrobiologii lekarskiej. Podręcznik dla studentów. Red. L. JABŁoŃSKI. Warszawa 1979, p. 11.

77 Polish Act of 5 December 2008 on the prevention and control of infections and infectious diseases in people (Dz.U. of 2008 no. 234 item 1570).

78 The CTBT anticipates establishment of the Comprehensive Nuclear-Test-Ban Treaty Organisation, while TPNW provision implementation will be supervised by the International Atomic Energy Agency. However, this will require concluding additional detailed agreements.

79 S. KraSner: Structural Causes and Regime Consequences: Regimes as Intervening Variables. In: International Regimes. Ed. S. KrASNER. Ithaca 1983, p. 1-2. 
and $11 \%$ for the Non-Proliferation and Disarmament Initiative (NPD) and the Vienna Group of Ten. ${ }^{80}$ The main objective of the export control regimes is to lay down export standards for dual-use products, i.e. those serving military and civilian purposes, which can be applied in WMD production. The regimes include drafting so-called control (threshold) lists which are regularly updated and constitute the basis for controlling the flow of prohibited materials and exchanging information between the member states. The most important regimes are: the Zangger Committee, the Nuclear Suppliers Group (NSG), the Missile Technology Control Regime (MTCR) and the Wassenaar Arrangement. ${ }^{\beta 1}$ The average number of participants in the abovementioned forums is 34 .

\section{Conclusions}

The second decade of the 21st century is coming to an end. It will go down in history as an exceptionally stormy period with an intensification of various events, phenomena and processes which have had an unfavourable influence on the security of countries and regions as well as supraregional security.

At the beginning of the present decade, a total of 81 state, non-state and internal conflicts were waged worldwide. At the end of 2018, that number increased to $162,{ }^{82}$ which was one of the highest values since 1975 , when the register was started; the greatest increase (57\%) concerned state conflicts. Some of them take place in the territories where weapons of mass destruction are present, can be

${ }^{80}$ The Global Initiative to Combat Nuclear Terrorism was announced in 2006 by Presidents G. Bush and V. Putin. It gathers 85 countries and aims at preventing nuclear terrorism via i.a. tracking the flow of nuclear materials. The Non-Proliferation and Disarmament Initiative aims at promoting the implementation of the arrangements made at the 2010 NPT Review Conference as well as intensifying the disarmament and non-proliferation effort. The Vienna Group of Ten promotes cooperation on the peaceful use of nuclear energy.

${ }^{81}$ The goals of the regimes are as follows: the Zangger Committee (the Nuclear Exporters Committee) aims at establishing a uniform interpretation of the provisions of art. III. 2. of the NPT; he Nuclear Suppliers Group promotes better understanding and support of nuclear export control (especially concerning dual-use goods); the Missile Technology Control Regime wishes to ensure the non-proliferation of missile goods and technologies as WMD delivery means; he Wassenaar Arrangement strives to increase transparency and responsibility in the transfer of conventional weapons and dual-use assets. Based on: Zobowiazania międzynarodowe Polski $w$ dziedzinie kontroli eksportu - informacje ogólne - https:// www.msz.gov.pl/pl/polityka_zagraniczna/polityka_bezpieczenstwa/nieproliferacja_bron1_ masowego_razenia/najwazniejsze_porozumien1a_1_1n1cjatywy_z_zakresu_nieprolifera cj1_1_rozbrojen1a_bmr/page_30286 (accessed: 14.07.2019).

2 Statistical data and terminology based on: the Uppsala Conflict Data Programme Conducted at the Uppsala University — https://ucdp.uu.se/\#/encyclopedia (accessed: 15.07.2019). 
transferred (manufactured) or remain within the range of the delivery means enabling their operational use. A combination of these facts justifies the thesis that the contemporary risk posed by this incredibly elaborate category of combat assets has increased. This is confirmed by the WMD and delivery means development programmes in various states as well as multiple instances of chemical weapon use in recent years.

Ten years ago, the hazard related to WMD (CBRN incidents ${ }^{83}$ ) was perceived first and foremost in the light of their use by non-state organisations, i.a. terrorist groups. The possible effects of releasing hazardous substances into the environment were also a source of concern. The possible military application was considered in extremely rare cases. Weapons of mass destruction, especially nuclear ones, were usually treated as Cold War relics. That conviction was strengthened by the faith in the effectiveness of bilateral (the United States Russia) and multilateral agreements aimed at arsenal reduction and supervision as well as elimination of certain weapon types. Those hopes have proved futile. Proliferation (both horizontal and vertical) remains an indisputable fact which clearly proves the limited effectiveness of international agreements. One must also highlight that recent years have seen an increase in the significance of nuclear weapons in the tactical configuration as an asset allowing its owner to exert pressure in international relations or constituting a deterring element in the owner's (or its allies') military doctrine. A consequence of this is nuclear weapon modernisation in many countries classified as nuclear states (under the NPT). It commenced recently and is scheduled for implementation in the oncoming years. Another disturbing phenomenon is the effort made to acquire this weapon by the states which are not parties to the NPT.

The topicality of the hazards related to the described problems and the great dynamics of the current events are proved by the fact that certain events, such as the meeting of Trump and Kim Jong Un in Panmunjom, a village located in the Korean Demilitarised Zone, or Iran's announcement of resuming the uranium enrichment programme, took place when this article was already being written. The topicality of the subject and its significance to the shape of the present and future international relations remain indisputable. All of this constitutes an inspiration to discuss these problems in a broader form which would permit a presentation and detailed description of the issues not included in this article for obvious reasons.

${ }^{83} \mathrm{CBRN}$ incident - every case related to the use of chemical, biological, radiological or nuclear weapons or CBRN devices, appearance of the action agents of such weapon or release of toxic industrial agents into the environment. See: M. MŁynARCZYK: Obrona przed bronia masowego rażenia w operacjach połaczonych DD/3.8(A). Bydgoszcz 2013, p. 7. 


\section{Bibliography}

http://nssarchive.us/NSSR/2010.pdf.htttps://2009-2017.state.gov/t/avc/rls/164722.htm (accessed: 2.05.2019).

https://www.state.gov/t/avc/newstart/290759.htm (accessed: 4.05.2019).

Treaty on the Prohibition of Nuclear Weapons, art. 1 - http://www.icanw.org/wpcontent/uploads/2017/07/TPNW-English1.pdf(accessed: 12.07.2019)

https://media.defense.gov/2018/Feb/02/2001872886/-1/-1/1/2018-NUCLEAR-POSTU RE-REVIEW-FINAL-REPORT.PDF (accessed: 14.06.2019).

Uppsala Conflict Data Programme conducted at the Uppsala University - https:// ucdp.uu.se/\#/encyclopedia (accessed: 15.07.2019).

https://web.archive.org/web/20150721195150 accessed: 28.05.2019).

http://www.rusemb.org.uk/press/2029 (accessed: 28.05.2019).

https://www.ctbto.org//accessed: 2.07.2019).

https://www.ctbto.org/nuclear-testing/history-of-nuclear-testing/types-of-nuclearweapons-tests/ (accessed: 2.07.2019).

https://www.globalzero.org/about-us/our-mission (accessed: 2.05.2019).

Zobowiazania międzynarodowe Polski $w$ dziedzinie kontroli eksportu - informacje ogólne — https://www.msz.gov.pl/pl/polityka_zagraniczna/polityka_bez pieczenstwa/nieproliferacja_broni_masowego_razenia/najwazniejsze_porozu mienia_i_inicjatywy_z_zakresu_nieproliferacji_i_rozbrojenia_bmr/page_30286 (accessed: 14.07.2019).

https://www.newsweek.pl/swiat/spoleczenstwo/pokojowa-nagroda-nobla-2017-ican/ 2gzcych (accessed: 12.06.2019).

Statement by UN Ambassador N. Haley of 27 March 2017 - https://www.polsatnews. pl/wiadomosc/2017-03-27/rozmowy-onz-o-zakazie-broni-atomowej-bez-usa-wiel kiej-brytanii-i-francji//accessed: 20.06.2019).

https://www.romereports.com/en/2017/11/10/pope-francis-on-nuclear-arms-internatio nal-relations-cannot-be-dominated-by-military-strength (accessed: 16.06.2019).

https://www.prezydent.pl/aktualnosci/wypowiedzi-prezydenta-rp/wystapienia/art, 420,wystapienie-prezydenta-rp-andrzeja-dudy-podczas-debaty-wysokiego-szcze bla-rady-bezpieczenstwa-onz.html (accessed: 16.06.2019).

https://www.tvn24.pl/wiadomosci-ze-swiata,2/rosja-armia-poswieci-szczegolnauwage-strategicznej-broni-jadrowej,700059.html (accessed: 2.06.2019).

https://www.tvp.info/16832858/putin-testuje-rakiete-i-straszy-bronia-atomowa-nukle arny-atak-mozliwy-ekspert-w-zasadzie-tak (accessed: 2.06.2019).

https://www.tvp.info/34294949/szef-nato-z-rezerwa-o-traktacie-onz-o-zakazie-bro ni-jadrowej-nie-zbliza-nas-do-celu (accessed: 12.06.2019).

https://www.wprost.pl/swiat/10107516/korea-polnocna-przekazywala-syrii-materialydo-tworzenia-broni-chemicznej-onz-opracowalo-raport.html (accessed: 4.07.2019)

Information note of 4 June 2019 by the Defence Attaché in India.

Information note of 6 June 2019 by the Defence Attaché in Moscow.

KACPRZYK A.: Polityka jadrowa USA a odstraszanie w Europie, notatki z wykładu.

War Studies University, 11 April 2018. Unpublished material. 
KosieradzKa A., ZaWiŁA-NiedźWIECKi J.: Zaawansowana metodyka oceny ryzyka w publicznym zarządzaniu kryzysowym. Kraków_Legionowo 2016.

Krasner S.: Structural Causes and Regime Consequences: Regimes as Intervening Variables. In: International Regimes. Ed. S. KRASNER. Ithaca 1983.

KRóL S.: Broń chemiczna $w$ drugie dekadzie XXI wieku. "Biuletyn CSOPBMR" 2016, Issue 6(16).

Kubowski J.: Broń jadrowa. Warszawa 2008.

Kupiecki R.: Visegrad Defence Cooperation: From Mutual Support to Strengthening NATO and the EU. A Polish Perspective. Report No. 35. Centre for European Policy, 2013.

LACHOWSK Z.: Nuklearne rozbrojenie i nieproliferacja: geneza, stan i perspektywy. "Bezpieczeństwo Narodowe" 2012, nr 22, II.

Metodyka prognozowania $i$ oceny strat $w$ rejonach uderzeń jądrowych. Warszawa 1991.

Michailiuk B.: Broń biologiczna jako zagrożenie bezpieczeństwa państwa. Warszawa 2015.

Michalski T.: Statystyka. Podręcznik. Warszawa 2004.

MŁYNARCZYK M.: Obrona przed bronia masowego rażenia w operacjach połaczonych DD/3.8(A). Bydgoszcz 2013.

National Security Strategy 2010.

Note of 19 June 2019 by the Defence Attaché in Washington.

Ostaszewski P.: Międzynarodowe stosunki polityczne. Zarys wykładów. Warszawa 2008.

Podstawy mikrobiologii lekarskiej. Podręcznik dla studentów. Red. L. JABŁoŃsKI Warszawa 1979.

Polish Act of 5 December 2008 on the Prevention and Control of Infections and Infectious Diseases in People (Dz.U. of 2008 no. 234 item 1570).

Protocol of 1990 to The Treaty on the Limitation of Underground Nuclear Weapon Tests — Threshold Test Ban Treaty (TTBT) of 1974.

Protocol to the Treaty Between The United States of America and the Russian Federation on Measures for the Further Reduction and Limitation of Strategic Offensive Arms.

„Przegląd Statystyczny Warszawy” 2018, nr 1.

ReDZIAK Z.: Niepewność w podejmowaniu decyzji. “Zeszyty Naukowe AON” 2013, nr 2(91).

Regulation of the Council of Ministers of 7 January 2013 on contamination detection and announcement as well as competence of authorities in these matters (Dz.U. of 2013 item 96).

SIPRI Yearbook 2018 Armaments, Disarmament and International Security.

Statement by Russian Minister of Foreign Affairs Sergey Lavrov of 20 January 2018 - https://zmianynaziemi.pl/wiadomosc/usa-buduje-nowe-bomby-atomowerosja-odmawia-podpisania-traktatu-o-eliminacji-broni (accessed: 12.06.2019).

SudA A.: Traktat o Catkowitym Zakazie Prób z Bronia Jądrowa - niedokończony rozdziat rozbrojenia nuklearnego. "Ekoatom" 2013, nr 9.

SzyBALSKi M.: Broń chemiczna w syryjskiej wojnie domowej 2011-2018. "Biuletyn CSOPBMR" 2018, nr 2(14). 
The Treaty Between The United States of America and the Russian Federation on Measures for the Further Reduction and Limitation of Strategic Offensive Arms. Treaty on the Prohibition of Nuclear Weapons.

US Department of State, Bureau of Arms Control, Verification and Compliance.

Warsaw Summit Communiqué Issued by the Heads of State and Government Participating in the Meeting of the North Atlantic Council in Warsaw 8-9 July 2016.

WĄTOR W.: Przeciwdziałanie terroryzmowi CBRN w świetle prawa polskiego. W: Zarzadzanie kryzysowe $w$ aspekcie zagrożeń terrorystycznych. Red. B. MicHAILiUK J., Solarz, J. Stempień. Warszawa 2019.

WĄTOR W.: Terroryzm CBRN - wyzwanie dla służb i administracji publicznej. W: Wyzwania i zagrożenia dla bezpieczeństwa międzynarodowego i narodowego pod koniec drugiej dekady XXI wieku. Red. K. CzORnIK, M. SzYnOL. Katowice 2017.

Wojciechowski J.: Pokojowy Nobel 2017 a broń jadrowa. "Biuletyn CSOPBMR" 2017, $\mathrm{nr} 4$.

Wolanin J.: Zarys teorii bezpieczeństwa obywateli. Ochrona ludności na czas pokoju. Warszawa 2005.

Zapobieganie stratom $w$ przemyśle. Red. A.S. Markowski. Cz. 3: Zarzadzanie bezpieczeństwem procesowym. Łódź 2000.

\author{
About the author \\ Col. Włodzimierz Wator, PhD — Head of the Chemical, Biologi- \\ cal, Radiological and Nuclear Training Centre (War Studies Uni- \\ versity).
}

